\title{
Late Holocene pollen record from Fiume Morto (Dead River), a palaeomeander of Tiber River near Ancient Ostia (central Italy)
}

\author{
Caterina Pepe $\cdot$ Laura Sadori 1 • \\ Valerie Andrieu-Ponel • Ferreol Salomon • \\ Jean-Philippe Goiran
}

Received: 29 November 2015/ Accepted: 6 July 2016

\begin{abstract}
Pollen and non pollen palynomorph analyses were carried out in a sediment core (MO2) drilled in the southern lobe of a palaeomeander, Fiume Morto (Dead River), in the Tiber delta area, near Ancient Ostia (central Italy). Since the Roman period, the Tiber River flowed close to Ancient Ostia and its saltworks, Salinae Ostiensis. The Tiber meander was cut off during the Tiber River flood of 1557 AD and transformed into an oxbow lake. During the nineteenth century the Fiume Morto pond was reclaimed and at present the area is about $3 \mathrm{~km}$ distant from the present shoreline and intensely transformed by human settlements. According to radiocarbon dates, the pollen record, not continuous, spans from the fourth century $\mathrm{BC}$ to the nineteenth century AD. It shows first a riverine phase before the meander cut off of sixteenth century $\mathrm{AD}$ and probably only the last centuries $\mathrm{BC}$
\end{abstract}

C. Pepe $\cdot$ L. Sadori $(\square)$

Dipartimento di Biologia Ambientale, Università 'La

Sapienza', Rome, Italy

e-mail: caterina.pepe@uniroma1.it

L. Sadori

e-mail: laura.sadori@uniroma1.it

C. Pepe

Dipartimento di Scienze della Terra, Università 'La Sapienza', Rome, Italy

C. Pepe $\cdot$ V. Andrieu-Ponel

IMBE, Aix-Marseille Université, CNRS, IRD, Avignon

Université, Aix-en-Provence, France

e-mail: valerie.andrieu-ponel@imbe.fr were preserved from erosion. The river deposits record riparian vegetation (mainly tamarisk and alder) with mesophilous (mainly deciduous oaks) and Mediterranean (mainly evergreen oaks, heather and olive tree) elements. The human presence is clear, probably related to the development of Ancient Ostia and evidenced by synanthropic taxa. The second phase corresponds to the oxbow lake formed after the meander cut off. Several peaks of pine pollen are tentatively ascribed to Tiber flood events: the first peak is found just in correspondence with the meander cut off at $1557 \mathrm{AD}$. The numerous floods we interpret in the following part of the diagram could be linked to the increase in extreme events and precipitation that occurred during the Little Ice Age. The last phase, in which freshwater plants are present and chenopods decrease, shows the saltworks abandonment that

\section{F. Salomon}

Department of Archaeology, Faculty of Humanities, University of Southampton, Southampton, Great Britain, UK

e-mail: F.Salomon@soton.ac.uk

\section{J.-P. Goiran}

Maison de l'Orient et de la Méditerranée - CNRS,

Université de Lyon, Lyon, France

e-mail: jean-philippe.goiran@mom.fr 
occurred in nineteenth century. This study turned out to be of key relevance to reconstruct the palaeoenvironmental evolution of the ancient Holocene Tiber meander during the last two and a half millennia.

Keywords Fiume Morto-Tiber River delta . Palynology · Late Holocene · Ancient Ostia - Central Italy

\section{Introduction}

Past environmental studies in coastal lands have been a recent challenge in earth sciences. Marginal lands such as deltaic, estuarine areas and coastal marshes are characterized by complex dynamics and marked environmental instability related to several factors such as changes in river discharge, climate, and sea level. In Mediterranean coastal areas the study is even more complex because extreme events have an intense impact in the hydrological cycle and human societies shaped the landscape since the prehistory (Kouli 2012; Djamali et al. 2013; Gambin et al. 2016; Morellón et al. 2016; Bellotti et al. 2016).

The Tiber delta plain, central Italy, was the subject of scientific investigations since the second half of nineteenth century (Oberholtzer 1875). The interest in the geomorphological and stratigraphic evolution of this area was almost continuous in the last century and even increased in the last few years (Bellotti et al. 2011, 2014; Giraudi et al. 2011; Salomon et al. 2016; Vittori et al. 2015) together with a boost in the study of the ancient Roman ports located in the area (Sadori et al. 2010a, b, 2015a, b; Mazzini et al. 2011; Keay 2012; Salomon et al. 2012; Giardini et al. 2013; Pepe et al. 2013; Goiran et al. 2014).

Vittori et al. (2015) used a 20-m-long core, ranging from 15,000 BP to the present time and drilled in the former marsh of Ancient Ostia to contribute to the reconstruction of the natural dynamics of Tiber delta. Bellotti et al. (2011) investigated the coastal evolution in the last 6000 years in the same area, focusing on the role of nature and humans in shaping the landscape. Pollen and macrofossil data of Mid-Holocene age are available from Maccarese (Di Rita et al. 2009) former lagoon in the delta area (Fig. 1). For the last 2000 years, the environment of the harbour basins of Claudius and Trajan and of the town of Portus have been reconstructed using pollen, plant macroremains and ostracods (Sadori et al. 2010a, b, 2015a, b; Mazzini et al. 2011; Giardini et al. 2013; Pepe et al. 2013; Delile et al. 2014). New studies outlined the landscape and the environmental features of the recently discovered port of Ostia (Goiran et al. 2014; Sadori et al. 2016c).

This investigation focuses on palynology of the area of Fiume Morto (Dead River), a filled up abandoned (1557 AD) Tiber River meander, located very close to Ancient Ostia and at about $3 \mathrm{~km}$ from present-day shoreline (Fig. 1). One of the first studies on the development of this former meander was carried out by Segre (1986). In 1992 Soprintendenza archeologica di Ostia excavated a 3-4 m deep trench in the inner bank of the abandoned meander and several shifting phases of the river were recognized (Arnoldus-Huyzendveld and Paroli 1995). Recently, deep cores drilled in collaboration with the Soprintendenza Speciale per i Beni Archeologici di Roma e Ostia, allowed us to reach the bedload of the palaeochannel between 10 and $12 \mathrm{~m}$ b.s.l. and to date the migrations of the palaeomeander of Ostia (Salomon et al. 2016).

The aim of the study is to reconstruct the palaeoenvironmental features of the paleomeander of the Tiber River using a sediment record down to about $10 \mathrm{~m}$, spanning from the foundation of Ostia (fourth century BC) to today, through pollen and Non Pollen Palynomorph (NPP) investigations.

Study site

Tiber River runs in central Italy and flows into the Tyrrhenian Sea (Fig. 1). The Tiber River splits in two branches in the delta area: Fiumara grande, the main branch, and Fiumicino the secondary one, flowing at NW of Ancient Ostia and at Fiumicino respectively. Fiumicino's branch largely coincides with the artificial channel, Fossa Traiana, excavated during the building of Claudius harbour in the first century AD. Until the ninth century $\mathrm{BC}$, the mouth of the Tiber River was located where nowadays Fiumicino channel runs. Between the eighth and fourth century BC the river shifted to the south, towards the present mouth (Giraudi et al. 2011). This shift must have occurred before the foundation of Ancient Ostia (Bellotti et al. 2011; Giraudi et al. 2011). Camuffo and Enzi (1995) reported the occurrence of 18 flood events of the Tiber 


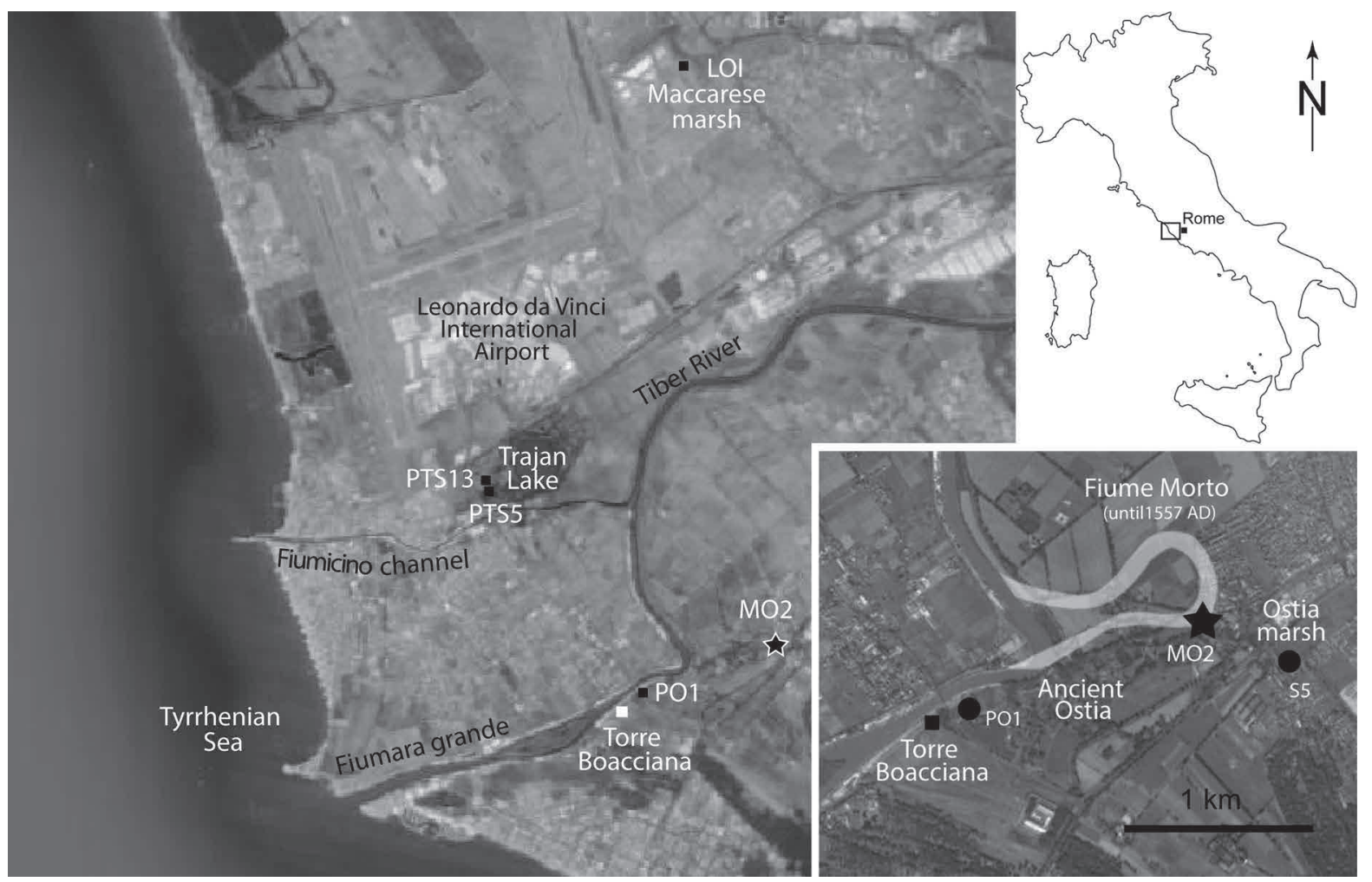

Fig. 1 Location map of Fiume Morto MO2 core (star), this article, and of the other pollen records (circles): Maccarese marsh, LOI core (Di Rita et al. 2009) Claudius and Trajan port, PTS5 and PTS13 cores (Sadori et al. 2010a, b; Pepe et al. 2013),

River between the end of the fifth century and the end of the first century BC. No important change in the direction of the course of the Tiber River occurred from the beginning of first century AD to the fifteenth century BC (Arnoldus Huyzendveld and Paroli 1995). From the Renaissance onwards the delta area was the site of frequent and severe floods (Camuffo and Enzi 1995 ) that caused a strong delta progradation (about $3 \mathrm{~km}$ since the Renaissance) with the development of beach ridges. The delta progradation is indicated by the existence of several towers built over time in different positions to stay close to the coast defending the Tiber mouth from possible attacks (Giraudi 2004, 2011). Torre Boacciana (Fig. 1), dating back to the beginning of fifteenth century, built close to the coast and nowadays around $3 \mathrm{~km}$ from it, is a clear example of the fast advance of the delta.

During the disastrous flood of 1557 AD, the Tiber River changed its course, cutting off a meander in the area of Ancient Ostia. According to a papal seal the meander was completely abandoned in $1562 \mathrm{AD}$
Ostia marsh, S5 core (Bellotti et al. 2011). Torre Boacciana is indicated by a square. Roman and Medieval saltworks were located in the area of the two marshes

(Pannuzi 2009). Then the meander became a characteristic oxbow lake and progressively an isolated swampy area, known from that moment on as Fiume Morto. In old topographic maps (Ameti 1696 and Cingolati 1704 as reported in Frutaz 1972) the cut-off meander named Fiume Morto is an oxbow. Amenduni (1884) reported that in 1880 Fiume Morto still existed. In the aerial photographs of 1911 made by the captain C. Tardivo (Shepherd 2006) the ancient meander shape was still clearly visible even if it was dried and filled up by sediments.

The ancient meander probably already existed at the time of Ancient Ostia foundation (Salomon et al. 2016). According to the legend (Livy: Ab urbe condita 1,33) the 4th king of Rome, Ancus Marcius, founded the city where the Tiber and the sea formed an angle (Dionysius of Halicarnassus: Antiquitates Romanae 3; 44), a fluminis flexum, river bend (Ovid: Fasti 4, 291). However the oldest archaeological evidence of Ostia dates back to fourth century BC (Meiggs 1973). Strabo and Livy report the presence of a fluvial harbour 
supplying the city of Ostia and Rome. The harbour location was recently found and confirmed by geoarchaeological data (Goiran et al. 2014; Hadler et al. 2015; Vött et al. 2015). Close to the city and therefore to the ancient meander, saltworks (Salinae Ostiensis) were present and probably they were in use from protohistoric to modern age (Pannuzi 2013). Until the building of harbours of Claudius and Trajan, inaugurated in $64 \mathrm{AD}$ and $112 \mathrm{AD}$ respectively (Testaguzza 1970), Ostia and its harbour were the principal trade centre of Rome. A progressive abandonment of the city occurred after the barbarian raids of fifth and sixth century $\mathrm{AD}$. In the medieval period, since ninth century, the building of Gregoriopoli, now Borgo (an Italian name for village) of Ostia (Pannuzi 2009) testifies its growth. During the fifteenth century Pope Giulio II ordered to build a castle (Giulio II castle), which was used as garrison of the fluvial harbour and seat of customs. The castle, first lapped by the ancient meander waters, after $1557 \mathrm{~s}$ flood lost its functions as the river had been shifted westward (Pannuzi 2004). Moreover the Tiber progressively eroded the northern part of Ancient Ostia, at the north of the Capitolium (Salomon et al. 2016). The only wealth of the area, in which malaria spread (Sallares 2006), was the extraction of salt until 1785 when the canals that transported sea water into saltworks stopped working. In 1802 Fiume Morto was described as a muddy, shallow and algal water body (Fea 1802). Between 1858 and 1868 technicians of the Papal States attempted to reclaim the coastal area but their attempts were not successful. After the establishment of the capital of Italy in Rome (1870) in 1878 the first law about the reclamation of Rome, Ostia and Maccarese areas was promulgated and in 1884 the reclamation of the area started. It was completed in 1930s under Mussolini. Today the Tiber delta area is an intensely man-made environment with towns, neighborhoods, roads, and the International Fiumicino airport.

Meteorological data (period 1971-2000) are available for the weather station of Fiumicino airport. The mean annual precipitation is $741 \mathrm{~mm}$, distributed in 72 days, with a minimum in summer and a maximum in autumn. The mean temperature of January, the coldest month, is $+8.6^{\circ} \mathrm{C}$, The mean temperature of August, the warmest month, is $+24.1^{\circ} \mathrm{C}$. The annual days of frost are 13 in average and the days with maximum temperatures above $30{ }^{\circ} \mathrm{C}$ are 23 (Aeronautica Militare-Servizio Meteorologico 2009).
The phytoclimate of Latium (Blasi 1994) ascribes the area to the region Mediterranean, Mesomediterranean thermotype, subhumid inferior ombrotype. Natural vegetation is scarcely preserved in the surroundings of Ostia. Patches of it are present in protected areas to the North and to the South of the Tiber delta, at Oasi di Macchiagrande (Lucchese 1996) and in Tenuta Presidenziale di Castel Porziano (Crescente et al. 2002; Gratani et al. 2010). The potential vegetation consists of deciduous mixed oak plain woods with evergreen and hygrophilous elements (Quercus cerris L., Quercus frainetto Ten., Quercus ilex L., Quercus pubescens Willd., Quercus robur L., Quercus suber L., Fraxinus oxycarpa L., Carpinus betulus L., Carpinus orientalis Mill., Ulmus minor Mill. and Ulmus laevis Pall). Evergreen sclerophilous elements (Arbutus unedo L., Cistus salviifolius L., Cistus incanus L., Erica arborea L., Juniperus oxycedrus L. var. macrocarpa (Sibth. \& Sm.), Juniperus phoenicea L., Olea europaea L., Pistacia lentiscus L. Phillyrea latifolia L., Quercus ilex L., Rhamnus alaternus L.) form the macchia along the coast and are also found inland in residual isolated stands (Blasi 1994).

\section{Materials and methods}

Three drillings were carried out in Fiume Morto area. A mechanical rotary coring device was used to this purpose. One sediment core, MO2 (Fig. 1), 23 m long, has been selected for the pollen study on the base of its sedimentological features. MO2 (GPS coordinate N: $41^{\circ} 45^{\prime} 31.269^{\prime \prime}$; E: $12^{\circ} 18^{\prime} 0.764^{\prime \prime}, 1.70 \mathrm{~m}$ a.s.1.) was drilled in the southern concavity of the palaeomeander (Salomon et al. 2016). On the basis of sediment characterization, sediments from 2.45 to $9.76 \mathrm{~m}$ were considered the most suitable for pollen analysis. The analysed sediments are mostly constituted by grey silty clay including few sandy layers. The core description and radiocarbon dates of MO2 core were carried out at University of Lyon, in France. The chronology of the MO2 core was assessed using 11 AMS radiocarbon dates. They have been calibrated using OxCal-curve (Reimer et al. 2013). In the interval (about $7 \mathrm{~m}$ long) selected for the pollen study three radiocarbon dates, obtained from pieces of wood, are available. The wood remain found at $9.70 \mathrm{~m}$ has provided a radiocarbon age of 
$2160 \pm 25$ years BP (cod. Lyon 8044, 356-112 cal. years $\mathrm{BC}$ ); the second one found at $8.88 \mathrm{~m}$ an age of $2035 \pm 30$ years BP (cod. Lyon 8780, 160 years BC50 years $\mathrm{AD}$; the last one (cod. Lyon 8788 ) at $2.60 \mathrm{~m}$ gave a modern date. According to the available dates, the portion of the core that was analysed for pollen spans from the fourth century BC to modern times. An about 10-cm-thick sandy layer occurring between 8.40 and $8.30 \mathrm{~m}$ indicates bottom erosion of the previous sediment and the flood leading to the meander cut off of 1557-1562 AD (Salomon et al. 2016).

Sixty eight samples with dry weight variable from 5 to $11 \mathrm{~g}$, were chemically processed according to the enrichment method of Goeury and Beaulieu (1979). This method uses, besides strong acids and bases, pollen flotation with liqueur de Thoulet, a mixture of cadmium iodide and potassium iodide $\left(2 \mathrm{~g} \mathrm{~cm}^{-3}\right)$. Lycopodium spore tablets (Stockmarr 1971) were not added to all samples.

Pollen identification was carried out using a transmitted light microscope at $400 \times$ and $630 \times$ magnifications. Oak pollen taxa have been distinguished as in Sadori et al. (2010a) in $Q$. deciduous group, $Q$. cerris $Q$. suber, and $Q$. ilex type; cereal pollen has been divided into Hordeum, Avenal Triticum and Secale. Particular attention was paid to the identification of Tamarix pollen, due to variable morphology: pollen atlases (Reille 1992-1998), reference pollen collections (laboratories of palynology of "La Sapienza" University of Rome and Modena and Reggio Emilia University) have been consulted.

An attempt to identify two different Pinus pollen taxa, Eurimediterranean species and Oromediterranean ones, has been carried out using pollen grain size (Roure 1985). In the case of pollen grains in clumps, each clump is counted as one pollen grain. TILIA software (Grimm 2011) has been used for data elaboration and spectra plots. Different pollen basis sums have been used to calculate the pollen percentage: the basis sum is including arboreal and herbaceous pollen, excluding spores, aquatic plants pollen and NPP.

\section{Results}

Pollen was not well preserved, except in few samples. Even if an enrichment method was used, only 44 out of 68 samples were rich enough in pollen to be analysed; for 36 of them pollen concentration counts are available. A total of 100 taxa, including all palynomorphs, have been identified. Pollen taxa are 87. The mean count of terrestrial spermatophytes is quite low, about 200 pollen grains. The very low pollen count is due to the occurrence of samples with very low pollen concentration, especially in the older part of the record. Sterile samples mostly occurred in the sediment interval from 7.36 to $6.66 \mathrm{~m}$. The diagrams (Figs. 2, 3, 4) have been divided in eight pollen zones with the help of CONISS (Grimm 1987).

Pinus pollen was generally severely damaged and the wings mostly found separated from bodies. Measuring was generally impossible; this is why separate curves for pine pollen taxa were not drawn. From 3.87 to $3.07 \mathrm{~m}$ pollen grains were evanescent, especially Cichorioideae, Amaranthaceae, Alnus and Pinus. This kind of bad preservation suggests problems in the taphonomical processes.

As at $8.06 \mathrm{~m}$ Hordeum pollen was found in clumps (36 \%, 23,000 on a total of 42,000 pollen grains $\mathrm{g}^{-1}$ ) and therefore excluded from the pollen sum of terrestrial plants.

The percentage of pollen of arboreal plants (AP) ranges from $10.2 \%(2.95 \mathrm{~m})$ to $90.5 \%$ (9.66 m). Total pollen concentration is rather variable, ranging from $260(8.36 \mathrm{~m})$ to 770,000 pollen grains $\mathrm{g}^{-1}$ $(4.37 \mathrm{~m})$. The samples with hiher biodiversity are found at 5.60 and $5.84 \mathrm{~m}$, with 54 recognized taxa each.

Zone MO2-1 (9.76-9.36 m)

A wood fragment from $9.70 \mathrm{~m}$ was radiocarbon dated at $1160 \pm 25 \mathrm{BP}(356-112 \mathrm{cal}$. years BC). AP percentage ranges from 68.3 to $90.5 \%$. The pollen concentration is very low (from 1000 to 5000 pollen grains $\mathrm{g}^{-1}$ ). Main arboreal taxa are deciduous $Q u e r$ cus (oaks), Alnus (alder), Tamarix (tamarisk), Pinus (pine), Olea (olive tree), and Erica (heather). At $9.66 \mathrm{~m}$, among NPPs, the alga Spirogyra and trilete spores of ferns are prevalent.

Zone MO2-2 (9.26-8.46 m)

A radiocarbon date of $2035 \pm 30$ years BP (160 BC$50 \mathrm{AD}$ cal. years) was obtained from a piece of wood at $8.88 \mathrm{~m}$ (Salomon et al. 2016). The AP, dominant as in the previous zone, ranges from $58.2 \%(9.26 \mathrm{~m})$ to 


\section{Fiume Morto (Ancient Ostia) - core MO2}
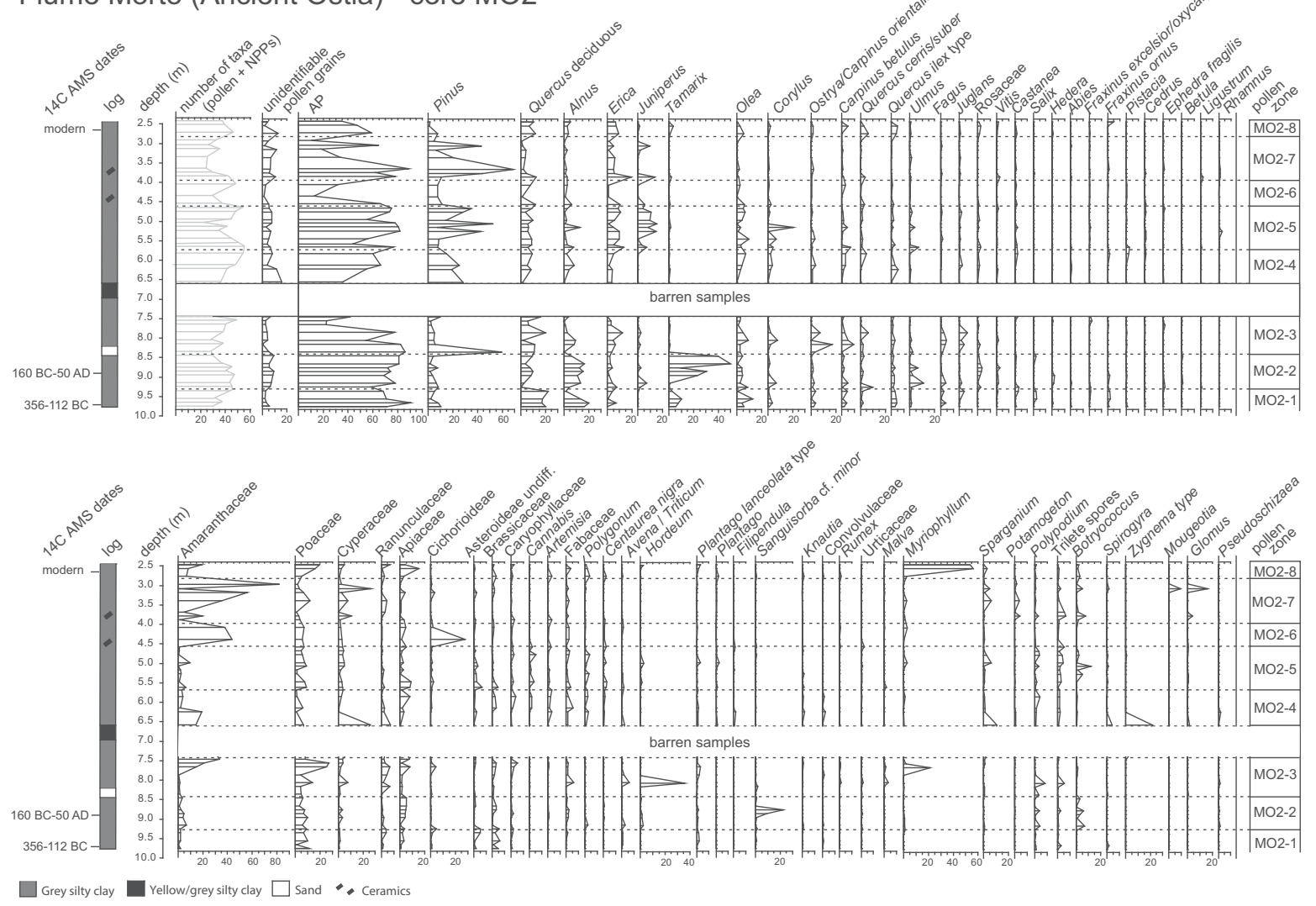

Fig. 2 Fiume Morto (Ancient Ostia). Pollen percentage diagram of MO2 core: selected pollen and NPPs curves

$81.1 \%(8.66$ and $8.46 \mathrm{~m})$. The pollen concentration is variable (from 280 to 60,000 pollen grains $\mathrm{g}^{-1}$ ). Dominant arboreal taxa are Tamarix, Alnus, deciduous Quercus, Olea, Erica, Ulmus (elm) and Pinus. The main herbaceous taxa are Poaceae (grasses) and Amaranthaceae. Tamarix in this interval shows the highest values (at $8.66 \mathrm{~m} 48.7 \%$ and at $8.46 \mathrm{~m}$ $42.3 \%$ ) except at the bottom sample of the zone $(9.26 \mathrm{~m})$ in which no tamarisk pollen is found. Alnus increases with rather high percentages: from $4.4 \%$ $(9.26 \mathrm{~m})$ to $16.4 \%$ (8.66 m). At $8.76 \mathrm{~m}$ Sanguisorba cf. minor occurred with a very high percentage: $22.6 \%$. Two peaks of microcharcoals are found at 8.96 and $8.76 \mathrm{~m}$ (Fig. 3).

Zone MO2-3 (8.36-7.46 m)

AP pollen is dominant $(86.1 \%)$ in the first half of the zone (from 8.36 to $7.86 \mathrm{~m}$ ) and then decreases down to $22 \%$. The pollen concentration is variable (from 230 to 93,000 pollen grains $\mathrm{g}^{-1}$ ). The prevalent taxa are deciduous Quercus, Ostrya/Carpinus orientalis, Erica, Alnus, Pinus, Olea, Poaceae, Amaranthaceae, Ranunculaceae, Myriophyllum. Among ferns and algae Polypodium and Botryococcus are the main taxa. A very high percentage of Pinus pollen (59.8\%) is found at $8.36 \mathrm{~m}$. It matches the lowest value of pollen concentration of the diagram (230 pollen grains $\mathrm{g}^{-1}$ ). Then Pinus rapidly decreases, reaching values similar to those of the previous zone $(2.3-10.1 \%)$ and alder increases from 0.4 to $9.4 \%$. At $8.06 \mathrm{~m}$ peaks of Olea $(9.4 \%)$ and Corylus $(7.8 \%)$ occur. In the same sample, peaks of Poaceae (14.2\%) Fabaceae $(6.3 \%)$ Avena/Triticum $(6.3 \%)$ are found. Moreover, in the same level, Hordeum pollen is found in clumps (even counting each clump as " 1 ", $36 \%$ is achieved). Juglans presents two peaks at $8.16 \mathrm{~m}$ $(4.1 \%)$ and at $7.86 \mathrm{~m}(6.7 \%)$. Concerning aquatic plants, Myriophyllum peaks at $21.2 \%$ at $7.66 \mathrm{~m}$. From 7.36 to $6.66 \mathrm{~m}$ all samples are barren. 


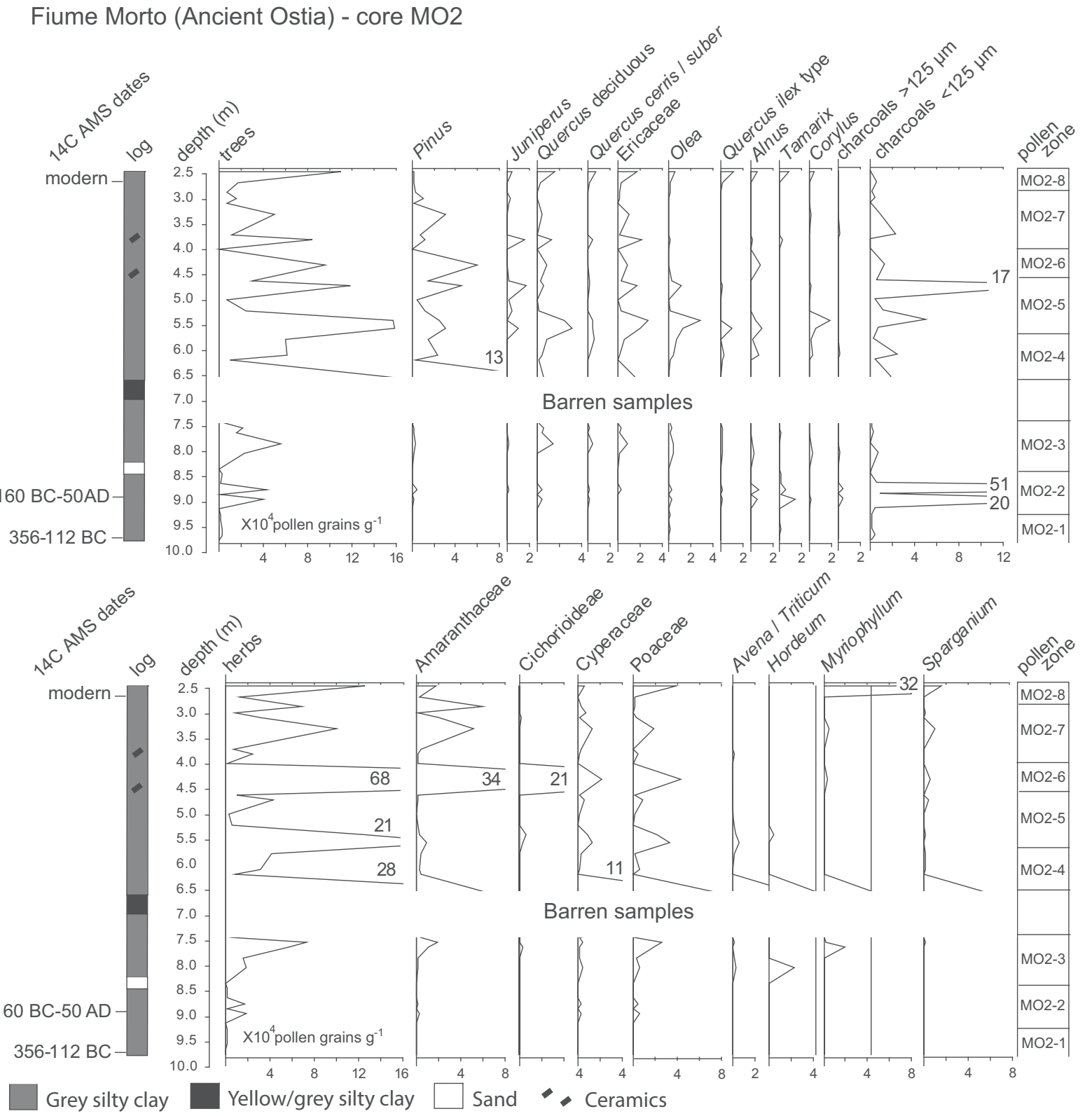

Fig. 3 Fiume Morto (Ancient Ostia). Pollen concentration diagram of MO2 core: selected pollen and NPPs curves

Zone MO2-4 (6.57-5.84 m)

The AP percentage values are between 35.8 and $76.8 \%$, increasing from the bottom to the upper samples. The pollen concentration is rather high (from 18,000 to 101,000 pollen grains $\mathrm{g}^{-1}$ ). The highest number of pollen taxa (54) is found at 5.84 and at $5.60 \mathrm{~m}$. The dominant arboreal taxa are: Pinus, deciduous Quercus, Erica, Alnus, Olea. Among the herbaceous plants Cyperaceae, Amaranthaceae, Poaceae, Apiaceae and Ranunculaceae are found. Sparganium, an aquatic plant, was detected. In this zone Zygnema type, Polypodium, Spirogyra, and trilete spores occur. In the first two samples Amaranthaceae are present with high percentage (18.9-14.5\%) that then drastically decrease. At $6.57 \mathrm{~m}$ a very high percentage of Cyperaceae $(21 \%)$ occurs. In the same sample peaks of Sparganium (10.9 \%), Zygnema type 
Fiume Morto (Ancient Ostia) - core MO2

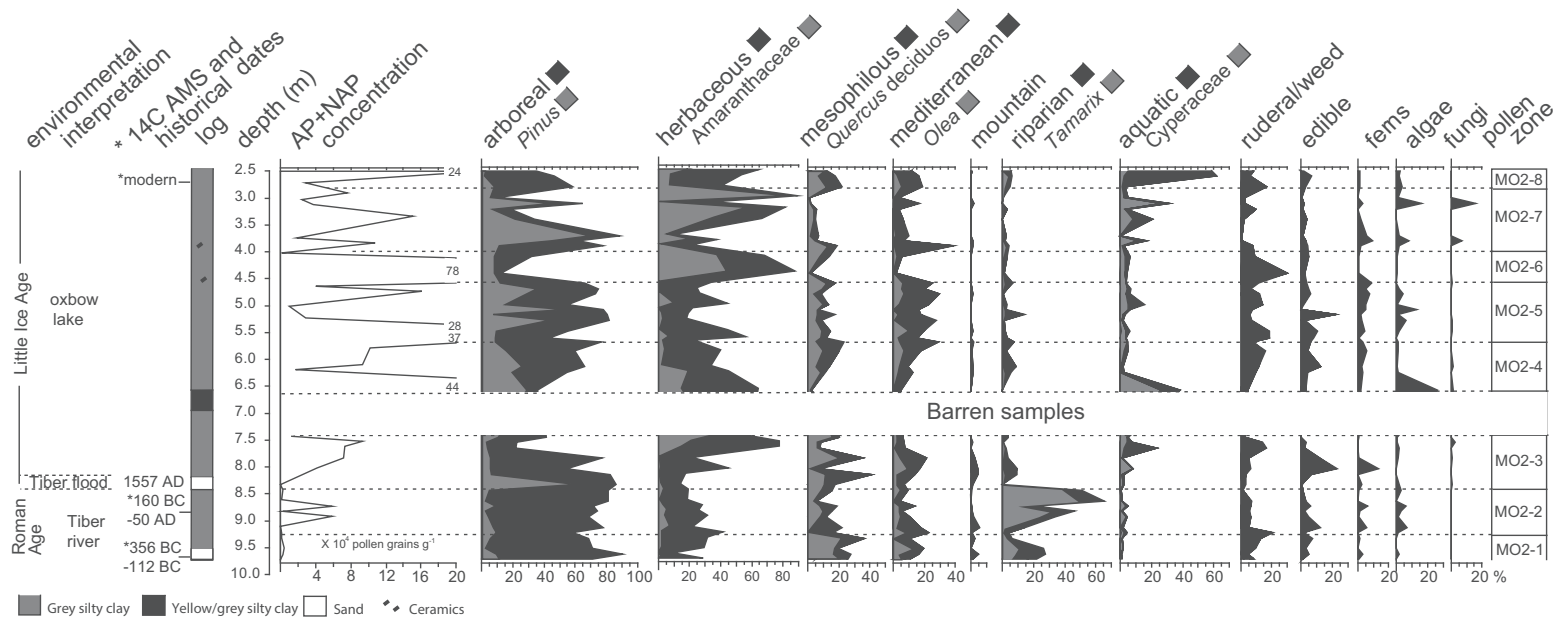

Fig. 4 Fiume Morto (Ancient Ostia). Pollen percentage diagram. Pollen "ecogroups": mesophilous (Acer, Carpinus betulus, Fraxinus excelsior/oxycarpa, Ostrya/Carpinus orientalis, Quercus deciduous, Q. cerris/suber, Tilia, Ulmus); mediterranean (Buxus, Cistus, Ephedra fragilis, Erica, Fraxinus ornus, Juniperus, Ligustrum, Myrtus, Olea, Pistacia, Phillyrea, Q. ilex type, Rhamnus); riparian (Alnus, Salix, Tamarix); aquatic (Alisma, Cyperaceae, Myriophyllum, Potamogeton, Sparganium, Typha); ruderal (Asteroideae undiff.; Cannabis,

$(22.1 \%)$ and Spirogyra $(4.2 \%)$ occur. At $6.14 \mathrm{~m}$ Cannabis (hemp) appears for the first time in the diagram, although with low percentages.

\section{Zone MO2-5 (5.60-4.67 m)}

This zone has arboreal plants between 43.6 and $82 \%$. The pollen concentration is high (from 29,000 to 365,000 pollen grains $\mathrm{g}^{-1}$ ). Main taxa are Pinus, deciduous Quercus, Erica, Juniperus, Corylus, Olea and Alnus. Poaceae, Cyperaceae, Amaranthaceae, Apiaceae are the principal herbaceous taxa.

The zone is characterized by three peaks of pine $(42.6 \%$ at $5.26 \mathrm{~m}, 52.3 \%$ at $5.06 \mathrm{~m}$ and $34.8 \%$ at $4.67 \mathrm{~m}$ ) matching the lowest pollen concentration of the zone. This zone is also featured by the presence of Cannabis (0.6-5.3\%). Botryococcus shows two peaks with rather high values at $5.26 \mathrm{~m}(5.4 \%)$ and at $5.06 \mathrm{~m}(12.1 \%)$. A peak of Sparganium is detected at $4.97 \mathrm{~m}(6.4 \%)$.

\section{Zone MO2-6 (4.37-4.07 m)}

An abrupt decrease in AP percentages distinguishes this zone. Non arboreal plants are dominant. The very
Caryophyllaceae, Amaranthaceae, Cichorioideae; Centaurea nigra, C. cyanus, C. undiff., Brassicaceae, Hedera, Malva, Plantago lanceolata type, $P$. cf. major, $P$. undiff., Polygonum, Rumex, Sambucus, Urticaceae); edible (Avena/Triticum, Castanea, Fabaceae, Juglans, Secale, Vitis); mountain (Abies, Betula, Fagus, Picea); fern (Polypodium, monolete and trilete spores); algae (Botryococcus, Mougeotia, Pediastrum simplex, Spirogyra, Zygnema type); fungi (Chaetomium, Gelasinospora, Glomus, Ustilago)

high pollen concentration (777,000 pollen grains $\left.\mathrm{g}^{-1}\right)$ found at $4.37 \mathrm{~m}$ is mainly due to Amaranthaceae (43.8\%) and Cichorioideae $(27.6 \%)$ and corresponds to low percentages of pine $(7.2 \%)$.

\section{Zone MO2-7 (3.87-2.95 m)}

AP percentages are between 10.2 and $89 \%$. The pollen concentration is high (from 19,000 to 150,000 pollen grains $\mathrm{g}^{-1}$ ). The dominant taxa are Pinus, Erica, deciduous Quercus, Juniperus, Amaranthaceae, Cyperaceae and Poaceae, Sparganium, trilete spores, Botryococcus, Mougeotia and Glomus. Minimum values of Amaranthaceae and pollen concentration correspond to maximum values of Pinus and viceversa.

Zone MO2-8 (2.75-2.45 m)

AP percentage shows values between 35.3 and $58.8 \%$. The pollen concentration is high (from 29,000 to 235,000 pollen grains $\mathrm{g}^{-1}$ ). At $2.75 \mathrm{~m}$, Pinus, deciduous Quercus, Erica, Olea, Alnus and Poaceae slightly increase, while Amaranthaceae decrease drastically (6.9\%). Considering aquatic 
plants, Myriophyllum reaches very high percentage values (53.7-56.1\%), with the presence of Sparganium, and Potamogeton.

Pollen data show that in the period between fourth century BC and present day the area surrounding Fiume Morto was covered by a mosaic of four main vegetation types (Fig. 4): mesophilous, mediterranean, riparian and aquatic plants. Mesophilous tree pollen (mainly formed by deciduous oaks) is from the deciduous coastal plain forest and presents values around $10 \%$. Mediterranean trees and shrubs probably formed a macchia vegetation with Erica, Quercus ilex type, Olea, Juniperus type. Riparian trees such as Alnus, Tamarix and Salix, characterized the Tiber delta around the active meander of Ostia. Aquatic herbs like Alisma, Myriophyllum and Potamogeton from freshwater environment mainly alternating with Amaranthaceae characterized the environment of the oxbow since the end of sixteenth century AD. The contemporary presence of deciduous, sclerophyllous and riverine vegetation in coastal zones was also typical of the ancient Roman ports of Naples, Pisa, and Rome (Sadori et al. 2015a, b). At Portus (Rome) there is also the evidence of salt production (Sadori et al. 2010a).

The bottom sediments of the analysed sequence (zone MO2-1) are constituted by medium size sand up to $9.50 \mathrm{~m}$ and then by grey silty clays (Salomon et al. 2016). The radiocarbon date 356-112 cal. years BC obtained at $9.70 \mathrm{~m}$ indicates an age compatible with the existence of Ancient Ostia. Pollen data reveal high percentages of riparian trees pollen, mainly constituted by alders and tamarisks, trees typical of deltaic environments. In particular, alders are riparian trees of freshwater environments, while tamarisks are salt resistant trees, adapted to arid and semi-arid climates, but able to reach with their roots deep water table. They can grow in riverside areas, in humid depressions and in sandy shoreline areas (Prada and Arizpe 2008). The presence of olive pollen in this zone with values up to $12.8 \%$ rather indicates local cultivation very close to the studied site. According to present day pollen studies (Florenzano et al. 2011), olive tree pollen rain reaches values around $6 \% 500 \mathrm{~m}$ distant from the groves. In a core from Ostia harbour (Goiran et al. 2014; Sadori et al. 2016c), rather high percentages of olive pollen were found in sediments of the same period and interpreted as cultivation in the area. Moreover, in S5 core of Ostia marsh, studied by
Bellotti et al. (2011), a significant increase of Olea is recorded around 400 years BC.

The sediments of the zone MO2-2, constituted by grey silty clay, are considered by Salomon et al. (2016) the last fluvial deposits of the Tiber River preserved from the period before the meander cut-off. The zone MO2-2 seems to span the long period from the last centuries of the Republican age, to at least the beginning of the Imperial period (first century AD) and probably until the flood of $1557 \mathrm{AD}$. The environment was dominated by riparian vegetation constituted by tamarisks and alders. Tamarisk curve reaches $49 \%$. Important values of tamarisk pollen were also found in the sediment cores from the harbour of Portus (Sadori et al. 2010a, b) and, to a lesser extent, of Ancient Ostia (Goiran et al. 2014; Sadori et al. 2016c). Ancient Romans probably used this plant to stabilize the dunes in the nearby area of Imperial harbours of Claudius and Trajan during the imperial age (Mazzini et al. 2011; Giardini et al. 2013). The presence of olive, grapevine, hazel and walnut, the increase of ruderal taxa and peaks in charcoal concentration testify human presence in the area. In the surroundings, a forest dominated by deciduous oaks is still present. The high percentage of pollen of Sanguisorba cf. minor could be derived from anther pieces transported by insects or preserved in fecal remains (Mercuri 2008; Bosi et al. 2011). The presence of Botryococcus could be linked to the input of freshwater through rivers (Miola et al. 2010).

The first pollen sample of MO2-3 is sandy, while the following ones are constituted by grey silty clays (Salomon et al. 2016). The peak of pine pollen occurring in the sandy sample at the base could be due to water transportation. Such high percentage of pine pollen cannot be considered representative of the local/regional pollen rain for two reasons: (1) the pollen grains found in the core appeared to be rather damaged, corroded and fragmented (single wings and bodies). The prevailing type was anyway the Eurimediterranean one; (2) regional data from central Italy suggest that pine forests were not widespread in the late Holocene (Magri and Sadori 1999; Mercuri et al. 2002), while it was surely cultivated as an ornamental and economic plant in the last centuries. A different explanation is therefore proposed: pine pollen grains are particularly overrepresented in marine and in large lake sediments because they float on water and can therefore be transported long away 
(Mercuri et al. 2012; Combourieu-Nebout et al. 2013; Sadori et al. 2016b). Thus, high percentages of Pinus can either indicate marine or freshwater water input. Probably this peak is linked to the disastrous, historically documented, flood of $1557 \mathrm{AD}$ rather than to a marine storm. The sandy layer is likely to correspond to fluvial sediments deposited during the flood. The strong reduction of riparian trees, and especially of tamarisk (from $49 \%$ of zone MO2-2 to less than $1 \%$ in this zone) is in agreement with this interpretation as in fifteenth century the delta strongly prograded (Giraudi 2004) and so the coastline moved far away from the coring site. Tamarisks, as already mentioned, are in fact favoured in coastal sites with saline water table. Pollen data therefore confirm the hypothesis advanced by Salomon et al. (2016) of a meander cut off occurring in this level. After the pine peak, alder pollen also decreases. Alder is the other main riverine tree, whose pollen could have been either water or air transported. The decrease of alder pollen suggests that the connection with Tiber River was interrupted. Mesophilous trees are abundant, and show a percentage decrease in correspondence with a peak of edible plants at $8 \mathrm{~m}$ (Fig. 4). These last include olive, grapevine, hazel, walnut and cereals. Hordeum was not included in cultivated taxa for its high percentage recorded at $8 \mathrm{~m}(36 \%$, Fig. 2) even if the occurrence of pollen clumps is an indication of local cultivation (Mariotti Lippi et al. 2015). After this sudden expansion of synanthropic taxa the diagram shows an increase of Myriophyllum that could be interpreted as the evidence of shallow freshwater conditions. This water plant in fact includes species not tolerant of high salinity (van Wijck et al. 1994) and generally grows in water up to $2 \mathrm{~m}$ deep (Azzella and Scarfò 2010). At the end of the zone Amaranthaceae, including salttolerant and ruderal herbs, increase. The increase of this taxon could be due to either the proximity to Salinae Ostiensis (located in the area of Ostia marsh) and Campus Salinarum Romanarum (in the area of Maccarese marsh) saltworks (Fig. 1), or to increased human impact. Pannuzi (2013) reported that Salinae Ostiensis had an important role, especially from Renaissance (fifteenth century) to Modern age while the Campus Salinarum Romanarum saltwork decreased its activity, due to the advancing of delta that caused more difficulties in the management of that area. The high level of salinity due to proximity of saltworks caused the increase of Amaranthaceae. The presence of chenopods at Maccarese lagoon is a further confirmation (Di Rita et al. 2009) of saltworks located also in the northern area of the delta (Pannuzi 2013; Morelli and Forte 2014). Another possibility could be that the presence of the salinity wedge, well documented in the Tiber delta area (Mikhailova et al. 1999; Pepe et al. 2013) favoured the growth of chenopods of marshy environments.

Cyperaceae and Poaceae are also found in significant percentages. In Poaceae, common reeds (Phragmites) are included. According to Passigli (2013) wetland reed vegetation (cannucetum) grew around saltworks and along the channels. Also Cyperaceae number a high amount of hygrophilous plants. The landscape and the water environment reconstructed for zone MO2-3 also fit well with the hypothesis of the formation of an oxbow lake with shallow freshwater (Fig. 4).

No pollen was preserved in the yellowish silty clay from 7.36 to $6.66 \mathrm{~m}$. It is difficult to understand the reason of this pollen depletion. A drying out of the cutoff meander should be ruled out for the level of the water table in the area (Capelli et al. 2007). Important hydrological works have been carried out in 1612 , when Fiumicino channel was definitely opened after silting probably due to floods (Testaguzza 1970; Salomon et al. 2012; Bellotti et al. 2014). Could these strong human interventions have a relation with the sediment transported to the oxbow?

The rather oscillating values of pine pollen from $6.57 \mathrm{~m}$ to top diagram could be either an artifact due to the percentage calculations (they mirror increase/ decrease of chenopods) or to flood occurrences. The fact that the total pollen concentration curve is mostly in antiphase with pine percentages (Fig. 4) clearly indicate that the increases of the last correspond to important changes in sedimentation, and so the first hypothesis results to be more reliable. According to Camuffo and Enzi (1995) several intense Tiber floods occurred also after 1557 AD. The seventeenth and eighteenth centuries are considered a period with various climatic perturbations and extreme events such as floods. In this period the delta advanced into the sea (Giraudi 2004). Torre Boacciana, built in 1420 $\mathrm{AD}$ on Roman ruins, is nowadays about $3 \mathrm{~km}$ far from the sea. The low percentages of alder indicate its presence in the surroundings (as along the Tiber shorelines). The continuous occurrence of a plant such as bur reed (Sparganium) strongly suggests that a 
freshwater environment with stagnant/slowly moving water was present in this second part of the diagram, after the barren samples, where the sediments are constituted by grey silty clays.

First a marshy, then a freshwater environment is rather clear for the samples of zone MO2-4 where, after two samples with medium percentages of Amaranthaceae, water plants and Poaceae occur together with freshwater algae such as Zygnema type and Spirogyra (Fig. 2). These last suggest the presence of shallow, stagnant freshwater pools. Anthropogenic indicators, edible and ruderal plants occur. Passigli (2013) reported that since the ninth century onwards, vegetable gardens and in particular vineyards were planted in the area, notwithstanding the presence of the wetland. Cannabis pollen occurs for the first time and is found in correspondence with decrease of Amaranthaceae. The cultivation of hemp is well documented during Roman and Medieval periods at Lago Albano and Lago di Nemi (Mercuri et al. 2002). In the last 2000 years Cannabaceae pollen was almost continuously found at the close wetland of Stagno di Maccarese (Di Rita et al. 2009).

In MO2-5 Mediterranean vegetation increases, while mesophilous one rather seems to decrease. Edible and ruderal plants are widespread as well, together with water plants and algae. Riparian trees present very low values. Amaranthaceae show very low values.

The freshwater environment detected by water plants in part of MO-4 and in MO-5 could be probably chronologically framed in the seventeenth century. Camuffo and Enzi reported thirteen floods during seventeenth century, four of which at 1606, 1637, 1660, and 1686 AD were particularly important. Fea (1831) reported that during seventeenth century Salinae Ostiensis were abandoned because the water inside the basins became fresh, due to malfunctioning communication of the channels with the sea. One of the channels, drawn in Alexandrian cadastre already in seventeenth century, probably passed through Fiume Morto (Fea 1831; Pannuzi 2013).

A different environment was shown in the zone MO2-6. Probably a decrease of water level at the Fiume Morto pool occurred: no aquatic plants and spores are detected, while high values of Amaranthaceae are found. The high percentages of Cichorioideae detected in this zone could be linked to less corrosion of the more resistant pollen exine (Bottema
1992) than rather to grazing activity (Florenzano et al. 2012). No coprophilous fungi, indicators of grazing, are in fact detected in these samples. An artificial drain out of the oxbow after Tiber River flooding(s) cannot be ruled out, considering the present day phreatic level (Capelli et al. 2007).

Zone MO2-7 is characterized again by two peaks of pine: such prevailing amounts were probably transported by Tiber River during floods that could have reached the oxbow lake. The other samples of the zone indicate the presence of aquatic plants typical of quiet water. The saltworks should have been still in use as Amaranthaceae show very high values until the end of MO2-7.

In MO2-8, in correspondence with a decrease of chenopods, an amazing increase of Myriophyllum occurs. This could be explained with the definitive abandonment of saltworks and the presence of watered lands.

According to Salomon et al. (2016) the core ends with reworked sediments above the top of the pollen diagram, ascribable to reclamation.

\section{Discussion}

In the first part of the diagram, ranging from fourth century BC to 1557 (roughly from the first radiocarbon date to the meander cut off, between 9.70 and $8.35 \mathrm{~m}$ ), the presence of a river environment close to a marine coast is hypothesized using sediment and pollen data. In this period, lasting a couple of millennia, the sedimentation was most likely not continuous and erosion could have occurred. At the end of the phase, the famous 1557 AD flood occurred. The life of Salinae Ostiensis is recorded by percentage changes of Amaranthaceae. In particular, before the flood of 1557 $\mathrm{AD}$, there are very low chenopods values, so no evidence of saltworks is detected. As historical sources indicate (Pannuzi 2013) that Salinae Ostiensis were surely active during Imperial Roman age and Middle Ages, so from the first century $\mathrm{AD}$ to the fifteenth century, MO2 core probably does not record both these periods.

In the second phase, ranging from 8.36 to $2.95 \mathrm{~m}$ and covering 3-4 centuries, the meander had become an oxbow lake. After the meander cut off, the water environment was in fact characterized by the presence of freshwater plants and algae. Pine's increases show 
an opposite trend in respect to pollen concentration values and are very likely linked to extreme events like floods. The fact that pine pollen floats in water induced us to hypothesize possible floods not clearly visible with other indicators, especially grain-size. The oxbow lake is in fact in distal position in the floodplain, away from the Tiber channel, and only few coarse rolled particles reached Core MO-2.

We suppose that when Tiber River overflowed the saltworks were damaged and brackish condition decreased. Pope Alessandro VII cadastre of 1660 (Pannuzi 2013) reports a canal, flowing the excess freshwater water from saltworks into Tiber River through or very close to Fiume Morto. Minima in chenopods could match this event.

The last phase, ranging from 2.75 to $2.45 \mathrm{~m}$, probably spans from the late eighteenth century to the reclamation works of nineteenth century. This phase shows a predominance of aquatic plants and the strong decrease of chenopods compatible with historical sources that reported that Fiume Morto appeared as a shallow pond with algae (Fea 1802). Salinae Ostiensis were completely abandoned in the late eighteenth century, due to insufficient canals management although several projects to make them operative again had been proposed (Pannuzi 2013). At the end of nineteenth century, reclamation works were undertaken in the area carried out by day labourers from Ravenna, who followed a working method already tried and tested in Romagna (Shepherd 2006).

Our interpretation of periodical floods reaching Fiume Morto seems to be confirmed by oral sources: between the end of nineteenth and the beginning of twentieth century in fact, during Tiber floods, the Fiume Morto area was inundated (Piero Bellotti, pers. commun.).

The increase of freshwater conditions was likely due to the increased precipitations that occurred during the Little Ice Age (LIA) and that caused repeated floods in the Mediterranean and central Europe (Glaser et al. 2010), a delta progradation phase in all the southern European deltas (Maselli and Trincardi 2013) and glacial advance in central Italy (Giraudi 2014).

Similar patterns and timing of events are found in the Mediterranean regions (Lespez 2003; Zielhofer and Faust 2008; Morellón et al. 2012, 2016; Piccarreta et al. 2011; Giraudi 2014; Gogou et al. 2016). The link between climate change and extreme events detected by fluvial hydrology is not straightforward as evidenced in a recent synthesis of Benito et al. (2015). Also palynology, generally of great help in investigating climate changes, in so recent times can fail. No evidence of LIA is for example found in the pollen diagram of Shkodra lake (Sadori et al. 2015a, b), while a prolonged period of relatively low evaporation and increased AP\% is found at Pergusa lake (Sadori et al. 2016a) and an intense erosional phase and expansion of the wetland recorded at Vravron (Kouli 2012). Recent records can be in fact strongly influenced by human impact and so climate reconstruction could be hindered and LIA hardly detectable (Peyron et al. 2013).

\section{Conclusions}

The interpretation of pollen diagrams form Fiume Morto resulted particularly complex. We had to take into account not only plant ecological factors, but also taphonomical processes. Pollen spectra in fact are not only mirroring the local vegetation, but contain important indications of environmental changes.

The Fiume Morto MO2 core shows dominance of forest canopy with alternating riparian, mediterranean and mesophilous arboreal elements, typical of a transition environment like a delta plain. Human presence and disturbance is clearly detected all over the investigated period, testified by the curves of cultivated and ruderal taxa indicating consisting human activity.

River sediments record, even if discontinuously, the landscape of ancient Ostia in the last centuries BC. Sediments of the first 1500 years AD are likely missing. The strong environmental change leading to the meander cut off and to the Fiume Morto oxbow formation, is ascribed to the flood occurring between 1557 and 1562 AD. The oxbow sediments mainly record the strong environmental changes of Little Ice Age and the vegetation changes caused by the related strong changes in hydrology.

- Palynology, well-known to be a powerful tool in reconstructing past vegetation landscape, turned out also extremely informative in interpreting river dynamics and water environmental changes.

- Pine pollen percentage peaks, matching very low pollen concentrations, are considered the evidence 
of floods that reached the small pond created after the meander cut off.

- Even sediments poor in pollen, apparently not suitable for palynological studies, can be valuable in understanding complex environmental dynamics in transition environments.

- The detected extreme events, as Tiber River flooding in the delta area, can be chronologically framed in the Little Ice Age.

- This record, even if likely discontinuous, provides important data on a period that is very little known in Italy and in the rest of the Mediterranean.

This study is a further step in the knowledge of the evolution of Tiber delta area and highlights complex river-humans interactions.

\section{References}

Aeronautica Militare-Servizio Meteorologico (2009) Atlante Climatico d'Italia 1971-2000, vol. Centro Nazionale di Meteorologia, Presidenza del Consiglio dei Ministri, Dipartimento della Protezione Civile Nazionale, Pratica di Mare, Roma. http://clima.meteoam.it/AtlanteClim2/pdf/ (242)Roma\%20Fiumicino.pdf

Amenduni G (1884) Sulle opere di bonificazioni della plaga litoranea dell'Agro Romano che comprende le paludi e gli stagni di Ostia, Porto, Maccarese e delle terre vallive di Stracciacappa, Baccano, Pantano e Lago dei Tartari. Eredi Botta, Roma

Arnoldus Huyzendveld A, Paroli L (1995) Alcune considerazioni sullo sviluppo storico dell'ansa del Tevere presso Ostia e sul porto-canale. Arch Laziale 12:383-392

Azzella MM, Scarfò F (2010) Atlante della vegetazione ripariale e sommersa della Riserva naturale del lago di Vico. Edizioni ARP, Roma

Bellotti P, Calderoni G, Di Rita F, D'Orefice M, D'Amico C, Esu D, Magri D, Martinez MP, Tortora P, Valeri P (2011) The Tiber river Delta Plain (Central Italy): coastal evolution and implications for the ancient Ostia Roman settlement. Holocene 21:1105-1116

Bellotti P, Davoli L, Terragoni C (2014) L'evoluzione del litorale tiberino negli ultimi 3000 anni sotto le forzanti naturali e antropiche. Studi costieri 22:33-43

Bellotti P, Calderoni G, Dall'Aglio PL, D’Amico C, Davoli L, Di Bella L, D'Orefice M, Esu D, Ferrari K, Bandini Mazzanti M, Mercuri AM, Tarragoni C, Torri P (2016) Middleto late-Holocene environmental changes in the Garigliano delta plain (Central Italy): which landscape witnessed the development of the Minturnae Roman colony? Holocene. doi: $10.1177 / 0959683616640055$

Benito G, Macklin MG, Zielhofer C, Jones AF, Machado MJ (2015) Holocene flooding and climate change in the Mediterranean. Catena 130:13-33

Blasi C (1994) Fitoclimatologia del Lazio. Fitosociologia 27:151-175
Bosi G, Bandini Mazzanti M, Florenzano A, Massamba N'siala I, Pederzoli A, Rinaldi R, Torri P, Mercuri AM (2011) Seeds/fruits, pollen and parasite remains as evidence of site function: piazza Garibaldi-Parma (N Italy) in Roman and Mediaeval times. J Archaeol Sci 38:1621-1633

Bottema S (1992) Prehistoric cereal gathering and farming in the Near East: the pollen evidence. Rev Palaeobot Palynol 73:21-33

Camuffo D, Enzi S (1995) The analysis of two bi-millenary series: Tiber and Po River floods. In: Jones PD (ed) Climatic variations and forcing mechanism of the last 2000 years. NATO-ANSI Series, 1: Global environmental change, vol 41. Springer, Berlin, pp 433-445

Capelli G, Mazza R, Papiccio C (2007) Intrusione salina nel Delta del Fiume Tevere. Geologia, idrologia e idrogeologia del settore romano della piana costiera. Giornale di Geologia Applicata 5:13-28

Combourieu-Nebout N, Peyron O, Bout-Roumazeilles V, Goring S, Dormoy I, Joannin S, Sadori L, Siani G, Magny M (2013) Holocene vegetation and climate changes in central Mediterranean inferred from a high-resolution marine pollen record (Adriatic Sea). Clim Past 9:2013-2042

Crescente MF, Gratani L, Larcher W (2002) Shoot growth efficiency and production of Quercus ilex L. in different climates. Flora 197:2-9

Delile H, Mazzini I, Blichert-Toft J, Goiran J-P, Arnaud-Godet F, Salomon F, Albarède F (2014) Geochemical investigation of a sediment core from the Trajan basin at Portus, the harbor of ancient Rome. Quat Sci Rev 87:34-45

Di Rita F, Celant A, Magri D (2009) Holocene environmental instability in the wetland north of the Tiber delta (Rome, Italy): sea-lake-man interaction. J Paleolimnol 44:51-67

Djamali M, Gambin B, Marriner N, Andrieu-Ponel V, Gambin T, Gandouin E, Lanfranco S, Médail F, Pavon D, Ponel Ph, Morhange C (2013) Vegetation dynamics during the early to mid-Holocene transition in NW Malta, human impact versus climatic forcing. Veg Hist Arcaheobot 22:367-380

Fea C (1802) Relazione di un viaggio ad Ostia e alla villa di Plinio detta Laurentino fatto dall'avvocato Carlo Fea. Antonio Fulgoni, Roma

Fea C (1831) Storia delle Saline d'Ostia introdotte da Anco Marcio quarto re di Roma dopo la fondazione di quella città. Stamperia della rev, Camera apostolica, Roma

Florenzano A, Benassi S, Mercuri AM (2011) Pioggia pollinica e qualità dell'aria: polline di Olea negli uliveti dal caso studio della regione Basilicata (sud Italia). Atti Soc Naturalisti Mat Modena 142:171-185

Florenzano A, Torri P, Rattighieri E, Massamba N'siala I, Mercuri AM (2012) Cichorioideae Cichorieae as pastureland indicator in pollen spectra from southern Italy. VII Convegno Nazionale di Archeometria (AIAr). Pàtron Editore, Bologna, pp 342-353

Frutaz AP (1972) Le carte del Lazio. II, Roma 1972

Gambin B, Andrieu-Ponel V, Médail F, Marriner N, Peyron O, Montade V, Gambin T, Morhange C, Belkacem D, Djamali M (2016) 7300 years of vegetation history and climate for NW Malta: a Holocene perspective. Clim Past 12:273-297

Giardini M, Giraudi C, Goiran JP, Masi A, Mazzini I, Pepe C, Sadori L (2013) Archaeobotanical investigations and human impact at the imperial harbour of Rome. Ann Bot (Rome) 3:199-205 
Giraudi C (2004) Evoluzione tardo-olocenica del delta del Tevere. Il Quaternario 17:477-492

Giraudi C (2011) The sediments of the 'Stagno di Maccarese' marsh (Tiber river delta, central Italy): a late-Holocene record of natural and human-induced environmental changes. Holocene 21:1233-1243

Giraudi C (2014) Coarse sediments in Northern Apennine peat bogs and lakes: new data for the record of Holocene alluvial phases in peninsular Italy. Holocene 24:932-943

Giraudi C, Magny M, Zanchetta G, Drysdale RN (2011) The Holocene climate evolution of the Mediterranean Italy: a review of the continental geological data. Holocene 21:105-115

Glaser R, Riemann D, Schönbein J, Barriendos M, Brázdil R, Bertolin C, Camuffo D, Deutsch M, Dobrovolný P, van Engelen A, Enzi S, Halícková M, Koenig SJ, Kotyza O, Limanówka D, Macková J, Sghedoni M, Martin B, Himmelsbach I (2010) The variability of European floods since AD 1500. Clim Change 101:235-256

Goeury C, Beaulieu JL (1979) A propos de la concentration du pollen à l'aide de la liqueur de Thoulet dans les sédiments minéraux. Pollen Spores 21:239-251

Gogou A, Triantaphyllou M, Xoplaki E, Izdebski A, Parinos C, Dimiza M, Bouloubassi I, Luterbacher J, Kouli K, Martrat B, Toreti A, Fleitmann D, Rousakis G, Kaberi H, Athanasiou M, Lykousis V (2016) Climate variability and socio-environmental changes in the northern Aegean (NE Mediterranean) during the last 1500 years. Quat Sci Rev 136:209-228

Goiran J-P, Salomon F, Mazzini I, Bravard JP, Pleuger E, Vittori C, Boetto G, Christiansen J, Arnaud P, Pellegrino A, Pepe C, Sadori L (2014) Geoarchaeology confirms location of the ancient harbour basin of Ostia (Italy). J Archaeol Sci 41:389-398

Gratani L, Varone L, Crescente MF (2010) Photosynthetic activity and water use efficiency of dune species: the influence of temperature on functioning. Photosynthetica 47:575-585

Grimm EC (1987) Coniss: a fortran 77 program for stratigraphically constrained cluster analysis by the method of incremental sum of squares. Comput Geosci 13:13-35

Grimm EC (2011) Tilia v1.6 computer program. Research and Collections Center, Illinois State Museum, Springfield

Hadler H, Vött A, Fischer P, Ludwig S, Heinzelmann M, Rohn C (2015) Temple-complex post-dates tsunami deposits found in the ancient harbour basin of Ostia (Rome, Italy). J Archaeol Sci 61:78-89

Keay S (2012) Rome, Portus and the Mediterranean Archaeological Monographs of the British School at Rome. The British School at Rome, London

Kouli K (2012) Vegetation development and human activities in Attiki (SE Greece) during the last 5,000 years. Veg Hist Archaeobot 21:267-278

Lespez L (2003) Geomorphic responses to long-term land use changes in Eastern Macedonia (Greece). Catena 5:181-208

Lucchese F (1996) Duna litorale del Rifugio WWF di Macchiagrande-Fregene. In: Dinelli A, Guarrera PM (eds) Ambienti di particolare interesse naturalistico del Lazio. Censimento del patrimonio vegetale del Lazio: quaderno, no. 2. Dipartimento di Biologia Vegetale, Università di
Roma "La Sapienza", Assessorato alla Cultura Regione Lazio, pp 199-201

Magri D, Sadori L (1999) Late Pleistocene and Holocene pollen stratigraphy at Lago di Vico (central Italy). Veg Hist Archaeobot 8:247-260

Mariotti Lippi M, Bellini C, Mori Secci M, Gonnelli T, Pallecchi P (2015) Archaeobotany in Florence (Italy): landscape and urban development from the late Roman to the Middle Ages. Plant Biosyst 149:216-227

Maselli V, Trincardi F (2013) Man made deltas. Sci Rep 3

Mazzini I, Faranda C, Giardini M, Giraudi C, Sadori L (2011) Late Holocene palaeoenvironmental evolution of the ancient harbour of Portus (Latium, Central Italy). J Palaeolimnol 46:243-256

Meiggs R (1973) Roman Ostia. Clarendon Press, Oxford

Mercuri AM (2008) Human influence, plant landscape, evolution and climate inferences from the archaeobotanical records of the Wadi Teshuinat area (Libyan Sahara). J Arid Environ 7:1950-1967

Mercuri AM, Accorsi CA, Bandini Mazzanti M (2002) The long history of Cannabis and its cultivation by the Romans in central Italy, shown by pollen records from Lago Albano and Lago Nemi. Veg Hist Archaeobot 11:263-276

Mercuri AM, Bandini Mazzanti M, Torri P, Vigliotti L, Bosi G, Florenzano A, Olmi L, Massamba N'siala I (2012) A marine/terrestrial integration for mid-late Holocene vegetation history and the development of the cultural landscape in the Po valley as a result of human impact and climate change. Veg Hist Archaeobot 21:353-372

Mikhailova MV, Bellotti P, Valeri P, Tortora P (1999) Intrusion of seawater into the River Part of the Tiber Mouth. Water Resour 26:679-686

Miola A, Favaretto S, Sostizzo I, Valentini G, Asioli A (2010) Holocene salt marsh plant communities in the North Adriatic coastal plain (Italy) as reflected by pollen, nonpollen palynomorphs and plant macrofossil analyses. Veg Hist Archaeobot 19:513-529

Morelli C, Forte V (2014) Il Campus Salinarum Romanarum e l'epigrafe dei conductores, Mélanges de l'École française de Rome-Antiquité 126-1

Morellón M, Perez-Sanz A, Corella JP, Buentgen U, Catalan J, Gonzalez-Samperiz P, Gonzalez-Trueba JJ, Lopez-Saez JA, Moreno A, Pla-Rabes S, Saz-Sanchez MA, Scussolini P, Serrano E, Steinhilber F, Stefanova V, Vegas-Vilarrubia T, Valero-Garces B (2012) A multi-proxy perspective on millennium-long climate variability in the Southern Pyrenees. Clim Past 8:683-700

Morellón M, Anselmetti FS, Ariztegui D, Brushulli B, Sinopoli G, Wagner B, Sadori L, Gilli A, Pambuku A (2016) Human-climate interactions in the central Mediterranean region during the last millennia: the laminated record of Lake Butrint (Albania). Quat Sci Rev 136:134-152

Oberholtzer F (1875) Le foci del Tevere. GB Paravia, Roma

Pannuzi S (2004) Castello di Ostia Antica: musealizzazione di ceramiche medievali e rinascimentali. Fasti on Line 16:1-3

Pannuzi S (2009) Il Castello di Giulio II ad Ostia Antica. All'Insegna del Giglio, Firenze

Pannuzi S (2013) La laguna di Ostia: produzione del sale e trasformazione del paesaggio dall'età antica all' età moderna. MEFR Moyen Age 125, 2. http://mefrm.revies.org/1507 
Passigli S (2013) Insediamento, risorse e rapporto uomo-ambiente nell'area del delta del Tevere fra i secoli X e XV. In: Roma, Tevere, Litorale. 3000 anni di storia, le sfide del futuro. Convegno Internazionale, Roma, 2013

Pepe C, Giardini M, Giraudi C, Masi A, Mazzini I, Sadori L (2013) Plant landscape and environmental changes recorded in marginal marine environments: the ancient Roman harbour of Portus (Rome, Italy). Quatern Int 303:73-81

Peyron O, Magny M, Goring S, Joannin S, de Beaulieu J-L, Brugiapaglia E, Sadori L, Garfi G, Kouli K, CombourieuNebout N (2013) Contrasting patterns of climatic changes during the Holocene across the Italian Peninsula reconstructed from pollen data. Clim Past 9:1233-1252

Piccarreta M, Caldara M, Capolongo D, Boenzi F (2011) Holocene geomorphic activity related to climatic change and human impact in Basilicata, Southern Italy. Geomorphology 128:137-147

Prada MA, Arizpe D (2008) Riparian tree and shrub propagation handbook. An aid to riverine restoration in the Mediterranean region, Generalitat Valenciana, Valencia

Reille M (1992-1998) Pollen et spores d'Europe et d'Afrique du Nord. Laboratoire de botanique historique et palynologie, Marseille

Reimer PJ, Bard E, Bayliss A, Beck JW, Blackwell PG, Bronk Ramsey C, Buck CE, Edwards RL, Friedrich M, Grootes PM, Guilderson TP, Haflidason H, Hajdas I, Hatté C, Heaton TJ, Hogg AG, Hughen KA, Kaiser KF, Kromer B, Manning SW, Reimer RW, Richards DA, Scott EM, Southon JR, Turney CSM, van der Plicht J (2013) Selection and treatment of data for radiocarbon calibration: an update to the International Calibration (IntCal) criteria. Radiocarbon 55. Radiocarbon 55:1923-1945

Roure JM (1985) Palinologia Iberica. Fam. 1 a 20. Cupressaceae a Betulaceae. Orsis 1:43-69

Sadori L, Giardini M, Giraudi C, Mazzini I (2010a) The plant landscape of the imperial harbour of Rome. J Archaeol Sci 37:3294-3305

Sadori L, Mercuri AM, Mariotti Lippi M (2010b) Reconstructing past cultural landscape and human impact using pollen and plant macroremains. Plant Biosyst 144:940-951

Sadori L, Allevato E, Bellini C, Bertacchi A, Boetto G, Di Pasquale G, Giachi G, Giardini M, Masi A, Pepe C, Russo Ermolli E, Mariotti Lippi M (2015a) Archaeobotany in Italian ancient Roman harbours. Rev Palaeobot Palynol 218:217-230

Sadori L, Giardini M, Gliozzi E, Mazzini I, Sulpizio R, van Welden A, Zanchetta G (2015b) Vegetation, climate and environmental history of the last 4500 years at lake Shkodra (Albania/Montenegro). Holocene 25:435-444

Sadori L, Giraudi C, Masi A, Magny M, Ortu E, Zanchetta G, Izdebski A (2016a) Climate, environment and society in southern Italy during the last 2000 years. A review of the environmental, historical and archaeological evidence. Quat Sci Rev 136:173-188
Sadori L, Koutsodendris A, Panagiotopoulos K, Masi A, Bertini A, Combourieu-Nebout N, Francke A, Kouli K, Joannin S, Mercuri AM, Peyron O, Torri P, Wagner B, Zanchetta G, Sinopoli G, Donders TH (2016b) Pollen-based paleoenvironmental and paleoclimatic change at Lake Ohrid (SE Europe) during the past $500 \mathrm{ka}$. Biogeosciences 13:1423-1437

Sadori L, Mazzini I, Pepe C, Goiran J-P, Pleuger E, Ruscito V, Salomon F, Vittori C (2016c) Palynology and ostracodology at the Roman port of ancient Ostia. Holocene. doi:10. $1177 / 0959683616640054$

Sallares R (2006) Role of environmental changes in the spread of malaria in Europe during the Holocene. Quatern Int 150:21-27

Salomon F, Delile H, Goiran JP, Bravard JP, Keay S (2012) The Canale Di Comunicazione Traverso in Portus: the Roman Sea Harbour under River Influence (Tiber Delta, Italy). Géomorphologie: Relief. Processus, Environnement 1:75-90

Salomon F, Goiran JP, Pannuzi S, Rosa C (2016) Long-term coevolution between the Roman city of Ostia and the Tiber River (Italy). Geoarchaeology (in press)

Segre A (1986) Considerazioni sul Tevere e sull'Aniene nel Quaternario. In: Il Tevere e le altre vie d'acqua del Lazio antico. Arch Laziale VII, 2:9-17

Shepherd EJ (2006) Il rilievo topofotografico di Ostia dal pallone (1911). Arch aerea 2:15-38

Stockmarr J (1971) Tablets with spores used in absolute pollen analysis. Pollen Spores 13:615-621

Testaguzza O (1970) Portus. Illustrazione dei porti di Claudio e Traiano e della citta di Porto a Fiumicino. Julia Editrice, Roma

Van Wijck C, Grillas P, Degroot CJ, Ham LT (1994) A comparison between the biomass production of Potamogetonpectinatus L. and Myriophyllum spicatum L. in the Camargue (southern France) in relation to salinity and sediment characteristics. Vegetatio 113:171-180

Vittori C, Mazzini I, Salomon F, Goiran JP, Pannuzi S, Rosa C, Pellegrino A (2015) Palaeoenvironmental evolution of the ancient lagoon of Ostia Antica (Tiber delta, Italy). J Archaeol Sci 54:374-384

Vött A, Fischer P, Hadler H, Ludwig S, Heinzelmann M, Rohn C, Wunderlich T, Wilken D, Erkul E, Rabbel W (2015) Detection of two different harbour generations at ancient Ostia (Italy) by means of geophysical and stratigraphica methods. In: von Carnap-Bornheim C, Daim F, Ettel P, Warnke U, Häfen im 1. Millennium A.D. Bauliche Konzepte, herrschaftliche und religiöse Einflüsse. Interdisziplinäre Forschungen zu Häfen von der Römischen Kaiserzeit bis zum Mittelalter, pp 23-34

Zielhofer C, Faust D (2008) Mid and Late Holocene fluvial chronology of Tunisia. Quat Sci Rev 27:580-588 